\title{
Do convencer ao interagir: algumas reflexões sobre contextos e percursos da publicidade brasileira
} Cláudia Pereira e Amanda Antunes

\section{Resumo}

A partir da observação de processos de transformação da narrativa publicitária brasileira ao longo de sua história, este artigo busca analisar tendências predominantes na publicidade em diferentes épocas. São apontados três períodos com distintas formas de abordagem. Com ênfase nas práticas contemporâneas, observa-se que a juventude e as tecnologias são elementos-chave nesse cenário.

Palavras-Chave

Publicidade. Juventude. Tecnologia. Interatividade.

Cláudia Pereira I claudiapereira@puc-rio.br Doutora em Antropologia Cultural pela Universidade Federal do Rio de Janeiro - IFCS/UFRJ. Pesquisadora e professora do Programa de Pós-Graduação em Comunicação da Pontifícia Universidade Católica do Rio de Janeiro - PUC-Rio

Amanda Antunes I amandaantunesrj@gmail.com Doutoranda em Comunicação da Pontifícia Universidade Católica do Rio de Janeiro - PUC-Rio

\section{Introdução}

Desde os primeiros registros da publicidade brasileira, passando pelo período da comunicação de massa até 0 surgimento das mídias com potencial interativo, a publicidade enfrenta 0 desafio de se adaptar às diferentes possibilidades de comunicação existentes em cada época. Como um sistema vivo, dinâmico e constituinte do organismo social, tal qual todo 0 campo da Comunicação, a narrativa publicitária vive um constante processo de remodelagem de suas formas, linguagens, estratégias e ferramentas utilizadas em função de alterações econômicas, políticas e culturais. De maneira geral, seu foco se constitui em propor a adesão de ideias e/ou a aquisição de produtos através de dinâmicas de comunicação que se adaptem tanto ao contexto social como aos avanços tecnológicos e alterações comportamentais da sociedade na qual está inserida.

Tendo como foco os elementos que marcaram o percurso da narrativa publicitária brasileira, influenciando, modelando e alterando os 
mecanismos estratégicos de sua abordagem e linguagem, este estudo busca observar as tendências predominantes nas diferentes épocas, que nos permite evidenciar, sob uma perspectiva ampla, características que demarcam três períodos distintos, quais sejam: convencimento, sedução e interatividade. Parte-se, também, de duas premissas: (1) a publicidade é uma narrativa que se sustenta em um conjunto de representações sociais que, como tais, se constroem, fundamentalmente, nas interações do cotidiano; (2) e, por consequência, confere significado a processos sociais que se estabelecem entre indivíduos, grupos e instituições. Neste sentido, dentre alguns possíveis processos sociais a serem considerados, um, em particular, é aqui ressaltado: 0 da juvenilização da sociedade. Como base de observação e argumentação, serão analisadas peças publicitárias datadas em diferentes contextos. Além disso, serão apresentadas entrevistas com profissionais, a fim de apontar as tendências que se apresentam na publicidade brasileira contemporânea, diante dos rearranjos midiáticos e dos distintos fenômenos comunicacionais que se estabelecem na sociedade hodierna.

Antes, porém, é importante ressaltar que a perspectiva abrangente desta proposta colabora para a observação de fenômenos mais amplos. 0 objetivo deste artigo é, portanto, levantar alguns pontos para reflexão, inspirando futuros trabalhos que, pertinentemente, podem se aventurar no aprofundamento de questões mais específicas.

\section{Uma breve reflexão sobre representações sociais e juventude}

Antes que se desenvolvam as discussões inicialmente propostas, é importante firmar as bases que sustentam algumas das reflexões que, mais adiante, se apresentam.

A primeira base teórica refere-se à ideia de "representação social". Quando aqui se faz referência ao "fenômeno das representações sociais", está se invocando, por definição, a teoria que baliza este estudo, entre outras possíveis a serem acessadas, que procuram construir um conhecimento sobre 0 tema em questão. Trata-se da teoria segundo Serge Moscovici (2011), para quem, com efeito, as representações sociais - imagens, construções coletivas, classe geral de ideias e crenças - são um "fenômeno" e não um "conceito". Sendo fenômeno - produto e efeito da interação social -, pressupõe uma dinâmica que carece na ideia de conceito - imposição estática e coercitiva.

Moscovici (2011) assume que:

Pessoas e grupos criam representações no decurso da comunicação e da cooperação. Representações, obviamente, não são criadas por um indivíduo isoladamente. Uma vez criadas, contudo, elas adquirem vida própria, circulam, se encontram, se atraem e se repelem e dão oportunidade ao nascimento de novas representações, enquanto velhas representações morrem. Como conseqüência disso, para se compreender e explicar uma representação, é necessário começar com aquela, ou aquelas, das quais ela nasceu. (MOSCOVICl, 2011, p. 41) 
Ao propor que a necessidade de se buscar a representação original, se assim podemos nos referir, aquela que deu origem a todas as outras, 0 autor baseia-se na afirmação de que as representações sociais procuram "tornar familiar algo não familiar, ou a própria familiaridade" (Moscovici, 2011, p. 54). Para ele, há "universos consensuais" que conferem uma espécie de segurança e harmonia no plano das ideias e do conhecimento, que se consolidam com a repetição de situações, gestos e ideias.

Em seu todo, a dinâmica das relações é uma dinâmica de familiarização, onde os objetos, pessoas e acontecimentos são percebidos e compreendidos em relação a prévios encontros e paradigmas. Como resultado disso, a memória prevalece sobre a dedução, o passado sobre 0 presente, a resposta sobre 0 estímulo, e as imagens sobre a "realidade". (MOSCOVICI, 2011, p. 55)

\section{A contribuição de Moscovici está,} principalmente, na perspectiva de uma representação social que se constrói coletivamente, a partir de diferentes espaços do mundo cotidiano, inclusive o midiático, cimentando o social, reafirmando a força da memória, buscando a familiaridade e estimulada pelo momento mesmo em que a não familiaridade insurge-se, ainda que momentaneamente, contra o que está posto para, em seguida, ser modificada, aproximada, identificada e, finalmente, vencida por força da necessidade de um universo consensual.

A publicidade, portanto, colabora para a continuidade da memória e da familiaridade, reforçando aquilo que já é conhecido. Ao mesmo tempo, esforça-se em introduzir o novo, concretizado no bem de consumo que está ali, afinal, para ser anunciado. Isso explica o motivo pelo qual os anúncios e comerciais mais adiante analisados, em especial naquilo que chamamos de "primórdios" da propaganda, estão tão "ancorados" (MOSCOVICI, 2011) em formas comunicacionais já conhecidas e reconhecidas pelo público para o qual se dirigem. Trata-se, portanto, de uma ancoragem na forma e no conteúdo, na medida em que se sustentam nos já "velhos" meios de comunicação, ainda que veiculados pelos "novos" (rádio e televisão, por exemplo), e também na "sedução" que, em um dado momento do desenvolvimento de sua narrativa, era próprio (ou familiar) do cinema hollywoodiano.

Um dos momentos históricos escolhidos para a presente análise, os anos 1950 e 1960, marca a chegada da cultura norte-americana, através, sobretudo, dos filmes que passam a também figurar no imaginário brasileiro. Humphrey Bogard, Elizabeth Taylor, Clark Gable, Ava Gardner, entre tantas outras estrelas, tornam-se modelos de masculinidade ou de feminilidade, que ganham vias de acesso através do consumo das modas, dos modos e dos gostos importados do american way of life. Edgar Morin (2009) já apontava a construção das diferentes formas 
de expressão da cultura de massa, nestas décadas, a partir de valores como o happy end, a felicidade, 0 amor, o feminino, entre outros. Este autor apresenta, ainda, a juventude, ou a "cultura juvenil", como um elemento insurgente neste período pós-guerra, e mais, como parte inerente da própria cultura de massas, naquele contexto. Os jovens, ao imitarem Marlon Brando e James Dean, como demonstra Morin (2006), e mais tarde Elvis Presley e 0s Beatles, assistindo aos seus filmes, dançando suas músicas e, especialmente, incorporando o seu estilo de vida rebelde, ajudam a consolidar o consumo e, consequentemente, os meios de comunicação de massa e toda a indústria que os sustentava.

Levando em conta, portanto, a importância desta "cultura juvenil" nestes anos entre 1950 e 1960, é imperativo considerar, como ponto de vista, o cotidiano das sociedades modernas ocidentais naquele momento. Em outras palavras, configurava-se uma grande revolução na forma como se estabelecia o convívio das gerações, apartadas por um abismo, pelos prejuízos materiais, morais e emocionais da Segunda Guerra Mundial. Tratava-se de um momento de ruptura, de "rachadura", para usar uma expressão de Moscovici (2011), que precisava ser "consertada":

ao ocorrer uma brecha ou uma rachadura no que é geralmente percebido como normal, nossas mentes curem a ferida e consertem por dentro o que se deu por fora. Tal processo nos confirma e nos conforta; restabelece um sentido de continuidade no grupo ou no indivíduo ame- açado com descontinuidade e falta de sentido. (MOSCOVICl, 2011, p. 59)

Assim é que a publicidade, narrativa das representações sociais, serve a este propósito, o de familiarizar 0 que é não familiar, ou o de "curar a ferida" - ou, como foi dito anteriormente, apresentar o "velho", introduzindo o "novo".

\section{Dos primórdios à atualidade em uma visão geral}

Os primeiros registros de anúncios impressos brasileiros datam por volta de 1800 com ofertas de escravos e propriedades rurais e urbanas, encontrados no jornal, sendo esta a forma de propagação preponderante (MARCONDES, 2001). Já no decorrer dos anos 1900, a população das cidades e, consequentemente, 0 mercado começaram a se formar e, com isso, produtos variados passaram a ser anunciados. Em geral, os anúncios se apresentavam, para os padrões atuais, de forma esteticamente rudimentar e com presença marcante do texto. Com o surgimento das primeiras revistas, eles deixaram de ter formato e visual simples, o qual se assemelha aos classificados atuais, ganhando ilustrações mais apuradas e cores.

Como no exemplo, os anúncios, em geral, tinham a informação como elemento fundamental e trabalhavam o propósito de evidenciar as funcionalidades e/ou qualidades 


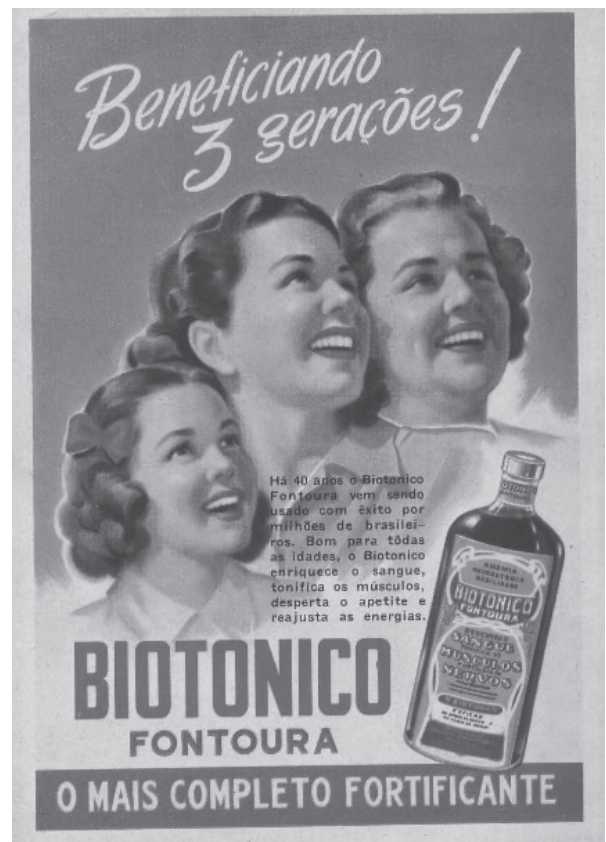

de uso do produto. Muitos eram ricos em adjetivos.

Uma evolução das técnicas e dos recursos, somada à influência norte-americana trouxeram inovação à década de 1930. Surgiram as primeiras fotos com produção, cores e estilo brasileiros. Porém, o que fez grande diferença para o país e a prática publicitária foi a chegada do rádio, constituindo, com sua expansão, "a primeira audiência de massa do século. Para a propaganda, isso significou o maior impacto de desenvolvimento de sua incipiente história" (MARCONDES, 2001, p. 27).

Em seus primeiros anos, a publicidade radiofônica ainda não havia encontrado seus caminhos próprios e apenas fazia a transposição, ancorada nas bases já conhecidas de forma e conteúdo, da mídia impressa para o áudio. Contudo, logo em seguida surgiram seus formatos exclusivos: os jingles $^{1}$ e spots ${ }^{2}$.

0 recurso da música que facilitava a memorização, somado à boa receptividade, fruto do componente afetivo gerado pelos cantores, apresentadores, programas e novelas, davam ao rádio um potencial considerável para a eficácia da mensagem dos anunciantes. 0 jingle criado para a "Brilhantina Glostora" é um bom exemplo. Ele foi produzido em cima de uma conhecida marcha de carnaval da década de 1940, chamada Aurora:

A elegância masculina Oh-oh-oh-oh Aurora Brilha mais com brilhantina Oh-oh-oh-oh Glostora... (Jingle Brilhantina Glostora, década de 1940) ${ }^{3}$ 
No entanto, a linguagem que predominava nos anúncios ainda se limitava à apresentação da funcionalidade do produto e à exaltação das qualidades do mesmo. Os anúncios radiofônicos do período possuíam uma evidente argumentação informativa, assim como os impressos permaneciam com a mesma lógica.

A década de 1940 revelou-se mais significativa para o rádio, que conquistava seu espaço com as novelas, os programas de auditório e jornalísticos. Os anúncios, ainda bastante adjetivados, começaram timidamente a ganhar argumentos mais subjetivos de venda e a incorporar um apelo emocional direcionado ao consumo, aproximandose (mesmo que ainda lentamente) do padrão da publicidade contemporânea. Nos anos 1950 e 1960, uma nova forma de abordagem tornou-se mais evidente.

Infere-se aqui que o discurso publicitário, nesse primeiro grande momento, caracteriza-se por seus argumentos baseados no apelo racional, na apresentação de elementos que se dirigem ao entendimento "lógico" da mensagem, com uma narrativa basicamente informativa, explicando a funcionalidade do produto e explicitando suas qualidades. A publicidade não explorava, ainda, um apelo às técnicas persuasivas tais quais são conhecidas na atualidade, mas, sim, uma abordagem do convencimento.

É necessário ressaltar, para compreensão da ideia apresentada, a diferença existente entre os conceitos de convencimento e persuasão que está sendo usada como base nesta análise. Embora muitos autores - e também o senso comum - não tratem com uma nítida distinção esses termos, muitas vezes tidos como sinônimos, é possível estabelecer uma diferença entre ambos, assim como aponta Carrascoza: "convencer é, pois, um esforço direcionado à mente, à Psique; persuadir é domínio do emotivo, próprio de Vênus, deusa do amor, daí a sua proximidade com a arte da sedução" (CARRASCOZA, 1999, p. 17).

A televisão chegou ao Brasil na década de 1950, de início, com uma produção ainda bastante experimental, com grande influência do rádio e sua linguagem já familiar. A partir de meados dessa década, os antigos apelos racionais

"Mensagem publicitária em forma de música geralmente simples e cativante, fácil de cantarolar e de recordar. Pequena canção, especialmente composta e criada para a propaganda de determinada marca, produto, serviço etc." (RABAÇA \& BARBOSA, 2001, p. 402)

"Texto publicitário para transmissão radiofônica [...]. Pode ter fundo musical ou efeitos sonoros, mas a força da mensagem está na palavra falada." (RABAÇA \& BARBOSA, 2001, p. 692)

Áudio disponível em: http://jovempan.uol.com.br/entretenimento/2011/03/jingle-da-brilhantina-glostora-arrasa-no-carnaval. html Acesso em: 11 abr. 2012 
cederam lugar a uma linguagem nova, com grande ênfase no discurso conotativo, com associações mais criativas que convidavam o receptor a "entrar no jogo". Sobretudo por volta dos anos 1960, quando há uma forte expansão do setor industrial e dos meios de comunicação de massa, a narrativa publicitária passa "a adotar uma lógica e uma linguagem próprias, nas quais a sedução e a persuasão substituem a objetividade

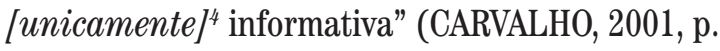
12), principiando seus primeiros passos para uma linguagem mais simbólica.

Percebe-se que elementos menos funcionais começam a ser trabalhados, prevalecendo os valores simbólicos que são associados ao produto. Como no exemplo apresentado, são atribuídas, ao produto anunciado, ideias de modernidade, elegância, atitude e relevância. Voltada para o público feminino, a narrativa publicitária constrói um ideal de estilo de vida, incitando em suas consumidoras o desejo do mesmo. 0s atributos simbólicos da mensagem conduzem os argumentos apresentados e justificam a proposta de consumo.

0 exemplo seguinte mostra um grupo de jovens alegres e descontraídos, em uma situação, podemos dizer, divertida, que revela, analogamente às situações do cotidiano dos próprios jovens, a importância da amizade, da afinidade e, principalmente, da aceitação e do pertencimento. A ideia de fazer parte de um grupo é, para a juventude, um valor essencial. É a partir da troca de experiências e do convívio com os amigos que se constituem as identidades e se concretizam os sentidos do mundo. Nesse "espaço", é onde se definem também as escolhas, inclusive, de bens de consumo, carregados de significações e valores comuns.

Como pode ser observado no decorrer de longos anos da publicidade - perdurando até os dias atuais -, prevalece uma linguagem extremamente sedutora e criativa, com forte apelo a um envolvimento emocional, enquanto a convocação ao consumo torna-se mais implícita e sutil, na medida em que a compra do produto torna-se mais insinuada, envolvida por conotações que transformam o bem de consumo em objeto simbólico integrante do imaginário dos consumidores. A desmaterialização do objeto apresentado no anúncio, resultado do crescente afastamento da proposta explícita de consumo, acarreta formas ao discurso argumentativo que direcionam o foco da mensagem aos valores simbólicos.

Passa a se construir, dessa forma, um discurso com ênfase na sedução, revestido de magia e encantamento, baseado em um jogo da ordem do desejo que tem por objetivo instigar, de forma criativa, a quem se quer seduzir, para que esse queira fazer parte do jogo

(BAUDRILLARD, 1991). 
Figura 2: Anúncio do produto Modess, da Jonhson e Jonhson, final da década de 1950.

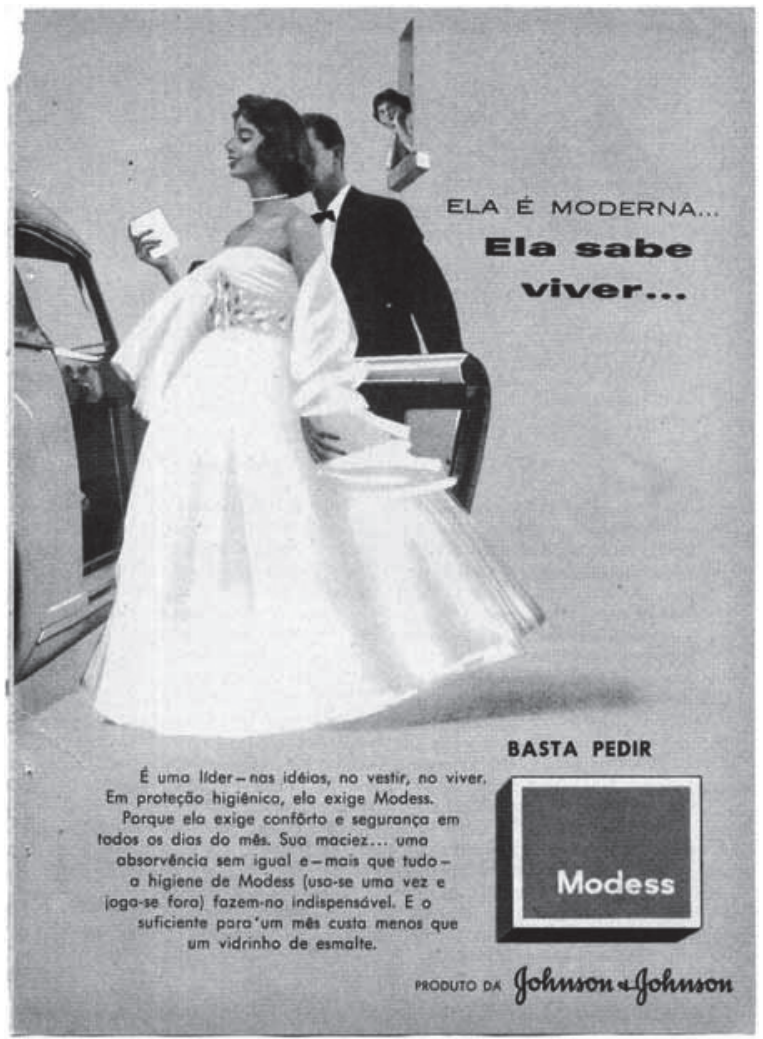

Figura 3: Anúncio do sabonete Rexona, década de 1960.

\section{Sempre cabe mais um} quando se usa Rexona.

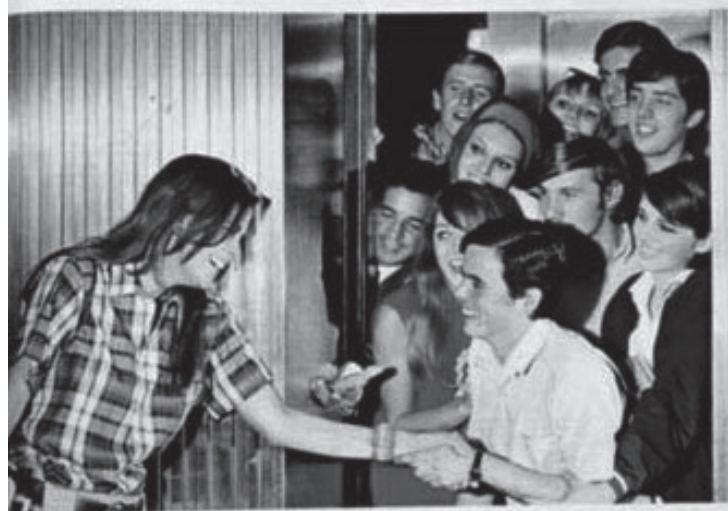

\section{Éo mais nôvo} sabonete-desodorante.

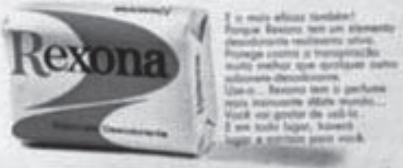


Conforme salienta Gilles Lipovetsky (2000),

estamos vivendo a apoteose da sedução. A publicidade libertou-se da racionalidade argumentativa, pela qual se obrigava a declinar a composição dos produtos, segundo uma lógica utilitária, e mergulhou num imaginário puro, livre da verossimilhança, aberto à criatividade sem entraves, longe do culto da objetividade das coisas (LIPOVETSKY, 2000, p. 8).

0 autor complementa argumentando que tal remodelagem no discurso publicitário contribui para aguçar 0 apetite do público receptor pelo lúdico, teatral e espetáculo. Trata-se de um processo de retroalimentação que faz, da publicidade, tanto reflexo da sociedade, como importante agente influenciador. Seu sentido se faz possível justamente porque suas mensagens são construídas a partir de significados comuns carregados de valores e representações compartilhadas socialmente.

Nesse jogo de espelhos que culmina no espetáculo do anúncio, pode-se dizer que o consumidor, 0 qual se identifica e é seduzido, é convidado a um exercício de imaginação que o desloca de uma realidade concreta a uma realidade experiencial, transformando o cotidiano em emoção, sob a lógica da fabulação e adesão, aproximando-se da vivência de situações especiais, fora da rotina, de lazer e prazer ou até mesmo mágicas. Há, portanto, uma estratégia de simulacro, no qual não se trabalha com verdades concretas, ao contrário, apresentase um universo que envolve emocionalmente cada receptor na fantasia proposta, esgarçando os limites entre a ilusão e a verdade. Todavia, a narrativa publicitária não é enganosa - e por isso seus receptores não podem ser considerados enganados -, mas também não é verdadeira, pois se constitui na seara da mágica. Nesse mundo dos anúncios, os sonhos da sociedade são expostos, "é onde tudo se resolve. 0 desejo é pleno, efetivado. Como no sonho, no mito, no conto de fadas, a lógica é a do desejo, o princípio o do prazer, o registro o do imaginário" (ROCHA, 1990, p. 140).

0 anúncio do sabonete LUX faz alusão ao ideal de beleza, comumente associado à saúde e à juventude. Seu argumento alerta as mulheres da importância de "controlar o tempo", mantendo a pele prevenida do envelhecimento, ancorado pela característica de maior duração do efeito do produto. 0 discurso estrategicamente baseado no ideal de juventude é notório, deixando também evidente a preponderância dos aspectos simbólicos implícitos na narrativa publicitária o desejo de uma aparência bela e juvenil - que representam, ao mesmo tempo em que norteiam, 0 imaginário e o comportamento femininos.

Anunciar está muito além da mera exposição e venda dos produtos. "Em cada anúncio vendemse estilos de vida, sensações, emoções, visões de mundo, relações humanas, sistemas de classificação, hierarquia em quantidades muito maiores que geladeiras, roupas ou cigarros" (ROCHA, 1990, p. 27). A partir da publicidade, 0 produto adquire sentido social, através de um apelo sedutor psicossociológico, na medida em 


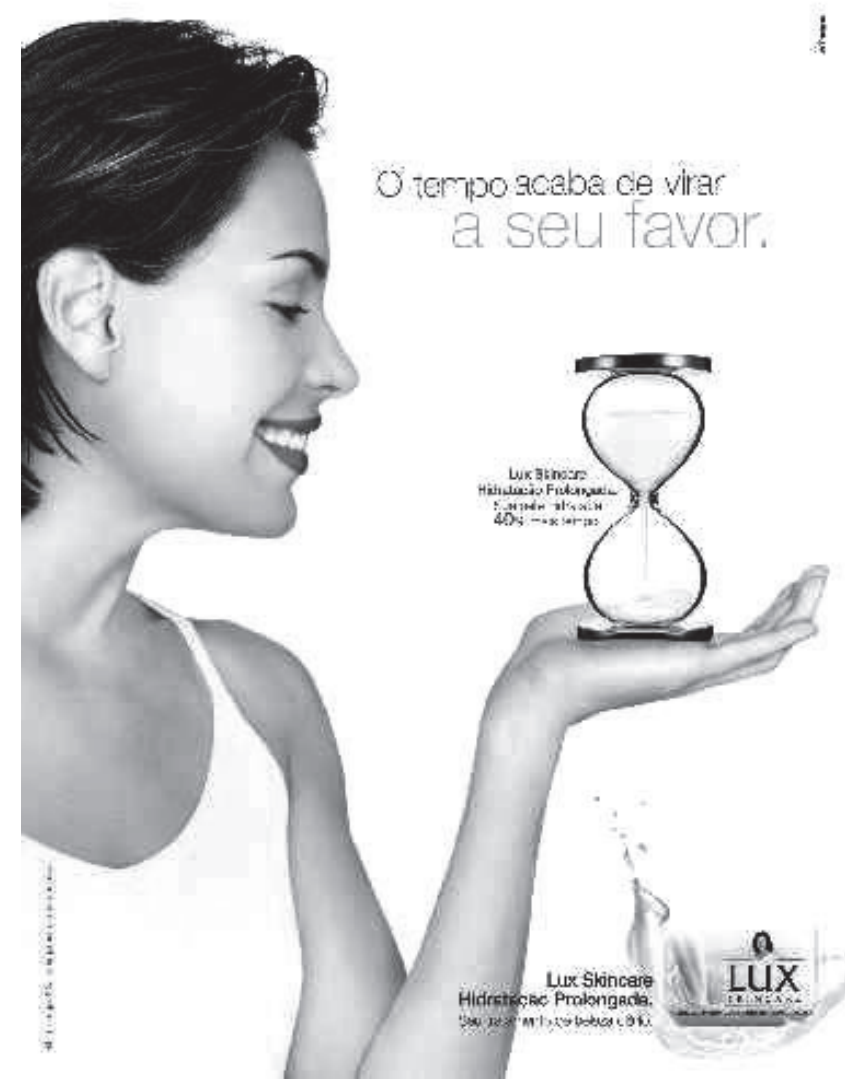

que se apresenta a um sujeito psíquico (dotado

Eu acordei, tirei meu pijama, fui para minha cama e depois dormi. Aí, eu fui tomar café, e deitei na cama, peguei o meu pijama, eu já fui logo para cama, yeh, yeh Eu fui para minha cama, Na cama com pijama... Locutor: A vida tem que ser mais que isso.

Barulho do motor da moto acelerando.

esse universo que atrai 0 consumidor com seu discurso calcado no valor simbólico, enquanto 0 0 anúncio marca um estilo de vida notoriamente próprio produto é deslocado a um segundo plano. juvenil, com um incansável desejo de emoções e Um bom exemplo é o comercial da marca Honda, com título "Na cama com pijama". Nele, um jovem aparece cantando uma música que narra uma situação cotidiana de sua vida: repúdio ao ócio. É do jovem que se espera uma postura proativa. Também é característico desse ideal um comportamento desbravador, libertário, corajoso e contestador, em especial, no momento 
Figura 5: Anúncio da Honda, década de 1990.

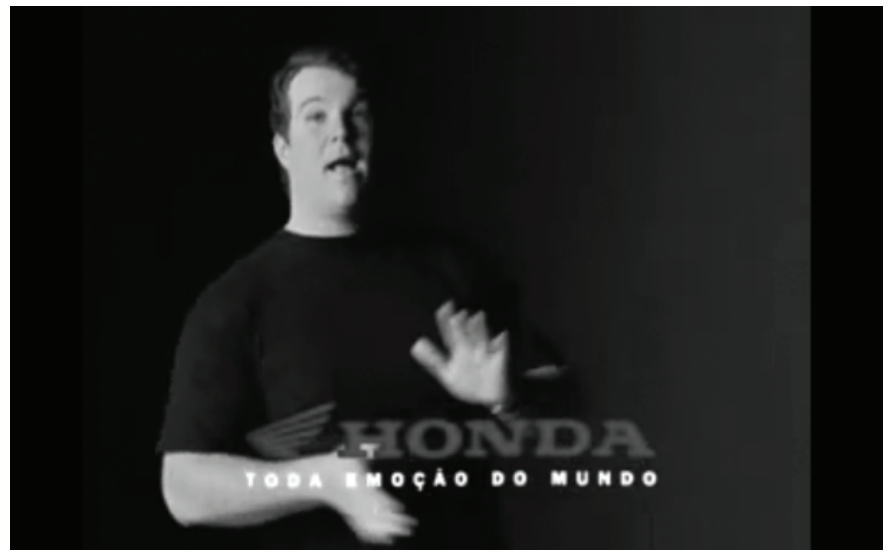

histórico no qual se encontrava o país, tendo experienciado, no início da década, o movimento "Caras Pintadas" e o impeachment do presidente Fernando Collor de Mello.

A publicidade, como fica claro no exemplo, dá concretude a conceitos consensuais compartilhados socialmente, ou, ainda, apresenta o bem material para o consumo, revestido de trajes comuns e perfeitamente familiares ao contexto do qual faz parte. É interessante observar também que o produto sequer aparece, sua "exposição" se dá somente através do som do motor da motocicleta sendo acelerada e a assinatura da marca ao final.

Jean Baudrillard explica que,

no fundo a 'demonstração' do objeto não persuade ninguém: serve para racionalizar a compra que de qualquer maneira precede ou ultrapassa os motivos racionais. Todavia, sem 'crer' neste produto, creio na publicidade que quer me fazer crer nele (BAUDRILLARD, 2002, p. 176).
Há, segundo Rocha, uma espécie de contrato tácito que faz com que os receptores dos anúncios publicitários acreditem "no impossível. E assim, o anúncio vai costurando uma outra realidade que, com base nas relações concretas de vida dos atores sociais, produz um mundo idealizado" (ROCHA, 1990, p. 26). É através desse "truque de mágica" que a publicidade se torna uma das principais produtoras do sistema simbólico que ordena a sociedade. Sua narrativa, inevitavelmente, tem a função de "educar", diferentemente dos tempos iniciais que se baseavam nas explicações utilitárias dos produtos, mas servindo para explicar formas de sociabilidade, enquanto orienta sobre o quê, onde, de que forma e em que momento consumir, em cada grupo social (ROCHA, 1990).

Torna-se, portanto, fácil compreender de que maneira a hegemonia da televisão (um dos principais meios de comunicação durante praticamente toda a metade do século passado, e ainda bastante expressiva neste século) contribui 
para a consolidação do aspecto mágico e do compromisso tácito que existe na relação do consumidor com a mensagem publicitária, esta fazendo parte, de modo muito presente, da vida e do cotidiano dos indivíduos e grupos.

Assim como se configurou uma narrativa sedutora até a década de 1980 e 1990, conforme apontado aqui, também seguiram-se os anos posteriores. 0 império do universo mágico e persuasivo do discurso publicitário permanece nos dias atuais. No entanto, novos elementos surgidos no decorrer do anos 1990 - apresentando-se de modo mais evidente na década seguinte - começam a reconfigurar esse cenário e inserir novas práticas comunicacionais que permitem vislumbrar outro aspecto predominante na forma de abordagem das mensagens publicitárias: a busca pela interatividade.

Os anos 1990 presenciam, com o advento da internet e os contínuos avanços da tecnologia digital, alterações nas bases materiais que constituem os processos comunicacionais da sociedade. É um período no qual "a interatividade passa a ser 0 ingrediente básico do discurso publicitário" (GALINDO, 2002, p. 23).

As possibilidades viabilizadas pela internet significam não apenas a facilidade de distribuição de informações e mensagens, mas também uma reconfiguração no papel e comportamento do receptor. A publicidade se apresenta neste cenário absorvendo rapidamente 0 discurso da interatividade ${ }^{5}$, lançando campanhas com novas propostas e formatos, adequando-se às transformações recorrentes nesse espaço dinâmico, de trocas simultâneas e propósito colaborativo, na tentativa de estabelecer uma comunicação com seu público baseada no potencial de grande envolvimento e construção de relacionamento. 0 s mecanismos estratégicos vão além do modelo de persuasão através de uma narrativa sedutora, e 0 consumidor passa a ser visto como elemento de fundamental importância para completar o universo da marca e contribuir na propagação das mensagens.

Em entrevista realizada com dez publicitários, oito deles ressaltaram a necessidade da publicidade contemporânea rever suas velhas fórmulas. Luíza Onório $0^{6}$ (diretora de criação) aponta que há uma grande probabilidade de os consumidores ignorarem, ou quase isso, a comunicação tradicional, uma vez que a quantidade de estímulos brigando por atenção é enorme e variada, e os receptores parecem desinteressados nos formatos tradicionais.

De fato, 0 atual momento da sociedade configurase em um quadro de excessos, com uma quantidade exacerbada de informações disponibilizadas, com inúmeras maneiras de acesso a elas, diversos 
estímulos sensoriais realizados conjuntamente e um universo de tarefas executadas ao mesmo tempo. Os produtos midiáticos e de entretenimento têm demandado mais atenção, ao mesmo tempo em que requerem mais participação dos consumidores.

Como se sabe, a atenção sempre foi algo extremamente caro ao mercado publicitário e se faz ainda mais necessária na atual conjuntura dos meios digitais. No geral, no modelo de comunicação massiva, as mensagens publicitárias se apresentam sob a lógica da invasão/intromissão, interrompendo determinada narrativa acompanhada pelo receptor. Para despertar o interesse para suas mensagens, a narrativa publicitária é recheada de estratégias sedutoras na busca da persuasão de seus argumentos. No entanto, esse formato parece perder cada vez mais força.

0 grande desafio atual, acredita Daniela Tomasi (diretora geral de planejamento), é como vencer a indiferença das pessoas, pois elas não querem ver publicidade. Felipa de Souza (diretora de planejamento) complementa afirmando que "0 público já prestou mais atenção na propaganda das marcas. Com menos opções de consumo de mídia e de entretenimento, a propaganda cumpria parte desse papel".
"A publicidade hoje está indo para as mãos de todos", afirma Nélio Rebento (consultor de comunicação). 0 potencial de propagação e construção da imagem de uma marca por parte do consumidor é hoje muito mais latente e evidente. Para Joseph Jaffe (2008), os consumidores atuais são inteligentes, pois se utilizam das diversas informações que têm acesso para conhecer profundamente 0 que desejam consumir; mas também céticos, quer dizer, bastante desconfiados e menos suscetíveis a serem impactados pela publicidade e mais abertos à influência dos demais consumidores.

Uma das características mais evidentes desse "novo" perfil, pode-se inferir, é a habilidade no aprendizado e uso das novas mídias e seus processos interativos. Com um comportamento mais inquieto - típico daquilo que se entende por uma conduta "jovem" -, os consumidores querem interferir, participar mais ativamente, interagir com a marca e trocar informações e experiências com os demais consumidores. É um perfil de comportamento que rejeita a "audiência passiva", a qual prevaleceu durante longas décadas de predomínio da televisão como meio de comunicação mais representativo no cotidiano das pessoas.

Luíza Onório, Daniela Tomasi, Felipa de Souza e Nélio Rebento são nomes fictícios, citados ao longo do texto, de quatro dos dez publicitários entrevistados, no período entre junho e julho de 2012.

A expressão audiência passiva está sendo utilizada aqui para enfatizar a oposição ao comportamento mais atuante, passível de retorno direto e imediato ao emissor e/ou interferência no conteúdo emitido, sem desprezar a inquestionável importância da atuação e participação do receptor em todo processo comunicacional. 
A importância do "boca a boca" para a construção da imagem de uma marca e, até mesmo, como influência na decisão de compra de um produto não é algo exatamente novo para a publicidade. A diferença, nos tempos mais recentes, está nas possibilidades viabilizadas pelas ferramentas disponíveis e na capacidade de fazer uso desse recurso. Certamente, as mídias digitais atribuem novos aspectos a esse boca a boca, como a rapidez na proliferação de uma mensagem, 0 alcance da comunicação sem limites geográficos, a possibilidade de contato direto e instantâneo com qualquer indivíduo, a qualquer momento, e a capacidade de propagação de uma mensagem para além do círculo de relacionamento daquele que a transmite.

A partir da necessidade que os indivíduos possuem de estabelecer contato e interagir com os outros, a publicidade faz uso das ferramentas disponíveis para incitar as trocas simbólicas e 0 compartilhamento espontâneo. Campanhas "virais" e ações promocionais em plataformas de redes sociais na internet são alguns exemplos de práticas publicitárias, cujo aspecto principal não é exatamente a divulgação do produto, mas, sim, a circulação da mensagem e o conjunto de valores simbólicos embutidos na marca, seduzindo e envolvendo o consumidor de modo que ele se torne, pelo menos naquele instante, uma âncora propagadora na sua rede de contatos.
Uma ação interativa realizada para divulgação da linha de produtos capilares Natura Plant ${ }^{8}$ ilustra a ideia. A Natura realizou uma interferência no momento da compra de ingressos de cinema no site ingresso.com perguntando ao consumidor se um dos ingressos comprados seria para uma mulher. Caso a resposta fosse sim, o comprador era convidado a gravar um vídeo em homenagem a ela. Foram gravados onze depoimentos e incorporados ao anúncio exibido nas sessões onde se encontravam os envolvidos, surpreendendo boa parte das homenageadas e do público geral. A ação foi filmada, registrando as reações das mulheres, e transformada em um vídeo para divulgação nos sites das redes sociais da Natura.

0 conceito trabalhado na campanha buscava transmitir a relação de cuidado e capricho que as mulheres costumam ter com seu cabelo e a importância disso na construção da própria identidade, com seus diferenciais e particularidades, explorando 0 apelo emocional envolvido.

Percebemos claramente neste exemplo que a publicidade não apenas está nas mãos do consumidor, conforme afirmou Nélio Rebento (consultor de comunicação), mas também é encenada por ele. É o indivíduo comum quem anuncia o produto e, consequentemente, quem legitima a veracidade do mesmo e da própria mensagem. Nesse caso, a apresentação do 
Figura 6: Ação da Natura no cinema, 2011.
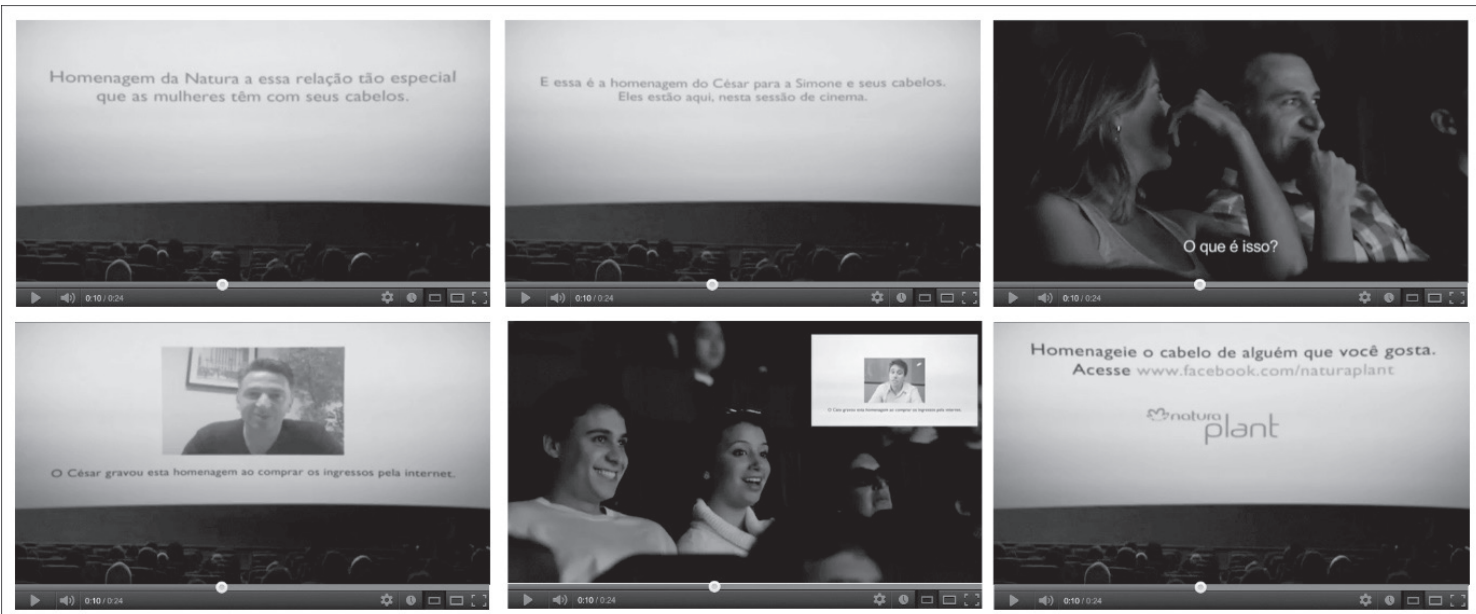

produto não é feita de maneira explícita e direta, mas, sim, através de um argumento, talvez ainda mais perspicaz, que se utiliza de uma prática comportamental cotidiana, comum e desejável nas relações, em especial, entre homem e mulher em tempos atuais: o elogio e a valorização dos cuidados com a beleza. Dessa forma, revela-se 0 que deve fazer a mulher, cuidar da sua aparência, e 0 que se espera do homem, o reconhecimento em forma de elogio. E, assim, percebe-se - ou esperase que seja percebido - o produto como propulsor desse "grande feito".

A participação dos consumidores que contribuíram com a produção dos vídeos complementa a mensagem original e reforça 0 conceito. Os aspectos divertido, afetivo, envolvente e emocionante garantiram considerável grau de atenção e boa repercussão à mensagem publicitária. Além do impacto positivo e direto nas pessoas envolvidas na ação, os demais receptores também foram impactados ao presenciar e compartilhar as emoções provocadas, gerando uma interação social simbólica dentro daquela sessão, assim como uma troca efetiva - o boca a boca - com outros consumidores para além das salas do cinema.

As plataformas de redes sociais, ou ainda a internet como um todo, tornam-se importantes aliadas para 0 estímulo à contribuição dos consumidores na propagação, em paralelo, a legitimação, de mensagens, uma vez que propiciam a fluidez de um conteúdo de forma fácil, ágil e "viral". Dessa forma, multiplicam-se as interações de marcas e consumidores e dos próprios consumidores, multiplicando também as trocas de informações e os valores simbólicos que ocorrem entre eles.

\section{Considerações Finais}

Diante do exposto, foi possível observar e apontar o processo de constante modificação e adaptação da narrativa publicitária, seus 
formatos, linguagem, recursos e práticas, perante as alterações contextuais que se apresentam na sociedade da qual faz parte.

Em um primeiro momento, prevaleceram abordagens de convencimento para se falar a linguagem e chamar a atenção do público correspondente à época. Passou-se, a seguir, para uma predominância de estratégias sedutoras, fruto da necessidade de se adaptar às mudanças do contexto social e econômico, quando 0 consumo e a lógica do espetáculo ganham corpo na sociedade e se tornam elementos edificantes das práticas sociais. Pode-se afirmar que, depois dos anos 1950 e 1960, a publicidade encontrou na cultura juvenil a chave para realizar a tarefa de reproduzir e reafirmar as familiaridades, estabelecendo sentido social àquilo que por ela é apresentado. Considera-se que, a partir daí, 0 mundo, paulatinamente, se "juvenilizou" (ROCHA e PEREIRA, 2009), principalmente através das práticas do consumo.

Com as tecnologias digitais, mais uma vez, a publicidade se vê diante da necessidade de rearranjar suas formas para se inserir e atuar nesse contexto que se instaura. Surge, então, um novo modo de estabelecer contato com o consumidor tendo como suporte 0 potencial interativo das novas mídias, sem, porém, alterarem-se as bases que sustentam seu propósito fundamental. Desse processo de juvenilização, também não escapa, evidentemente, a relação com a tecnologia, já que, na construção social mesma da ideia de juventude, a noção de "inovação" é uma constante. A juventude, enfim, é um "conceito publicitário" pronto e eficiente para anunciar qualquer coisa para qualquer idade (PEREIRA, 2010).

Uma mensagem publicitária, antes compartilhada somente na rede de contatos de proximidade física e afetiva de cada consumidor, encontra, no ambiente digital, a situação propícia para se propagar entre consumidores diversos e geograficamente distantes. É preciso, para tanto, facilitar o processo de distribuição, oferecendo as ferramentas necessárias a fim de potencializar os rumores (ROSEN, 2001, p. 191).

Para atrair o "novo receptor", conectado e ativo, as estratégias se voltam a proporcionar, com o suporte da tecnologia, novas formas de envolvimento com esse público, apostando na produção de linguagens mais sedutoras através de processos interativos com alto grau de experimentação intelectual e sensorial, ancorados em distintos valores de uma cultura juvenil contemporânea e seu fim norteado pela sociabilidade.

Com este apanhado, buscou-se observar os fatores que transitam e alteram percepções e contextos em diferentes épocas e, com isso, refletir sobre as tendências contemporâneas da comunicação publicitária e as chamadas "práticas interativas", estabelecendo também a notória e significativa correlação entre publicidade, juventude e tecnologia. 


\section{Referências}

ANTUNES, Amanda. Do afetivo ao efetivo: um estudo sobre interatividade e práticas publicitárias. 2013. 142

f. Dissertação (Mestrado em Comunicação) - PUC-Rio, Rio de Janeiro. 2013.

BAUDRILLARD, Jean. Da sedução. São Paulo: Papirus, 1991.

0 Sistema dos Objetos. São Paulo:

Perspectiva, 2002.

CARRASCOZA, João A. A evolução do texto

publicitário. São Paulo: Futura, 1999.

CARVALHO, Nelly de. Publicidade: a linguagem da sedução. São Paulo: Ática, 2001.

GALIND0, Daniel dos Santos. Propaganda Inteira e

Ativa, São Paulo: Editora Futura, 2002.

JAFFE, Joseph. 0 declínio da mídia de massa: por que os comerciais de TV de 30 segundos estão com os dias contados. São Paulo: M. Books, 2008.

LIPOVETSKY, Gilles. Sedução, publicidade e pósmodernidade. Revista FAMECOS. Porto Alegre, v. $1, \mathrm{n}^{0}$ 12, p. 7-13, 2000.

MARCONDES, Pyr. Uma história da propaganda brasileira. Rio de Janeiro: Ediouro, 2001.

MARTINS, Zeca. Propaganda é isso aí! São Paulo: Futura, 1999.

MORIN, Edgard. Juventude. In: Cultura de massas do século XX: 0 espírito do tempo I: neurose. Rio de Janeiro: Forense Universitária, 2009.

. A Crise Juvenil. In: Cultura de

massas do século XX: 0 espírito do tempo II: necrose. Rio de Janeiro: Forense Universitária, 2006.

MOSCOVICI, Serge. Representações sociais: investigações em psicologia social. Petrópolis: Ed. Vozes, 2011. estratégico para a publicidade. In: Revista

Comunicação, Mídia e Consumo. São Paulo, vol.7, nº 18 p. 37-54, março, 2010. Disponível em http://revistacmc. espm.br/index.php/revistacmc/article/viewFile/184/182

RABAÇA, Carlos Alberto \& BARBOSA, Gustavo

Guimarães. Dicionário da Comunicação. Rio de Janeiro: Elsevier, 2001.

RAMOS, Ricardo \& MARCONDES, Pyr. 200 anos de propaganda no Brasil: do reclame ao cyber-anúncio. São Paulo: Meio \& Mensagem, 1995.

ROCHA, Everardo P. Guimarães. Magia e capitalismo: um estudo antropológico da publicidade. São Paulo: Brasiliense, 1990.

ROCHA, Everardo; PEREIRA, Cláudia. Juventude e consumo: um estudo sobre comunicação na cultura contemporânea. Rio de Janeiro: Ed. Mauad, 2009.

ROSEN, Emanuel. Marketing boca a boca: como fazer com que os clientes falem de sua empresa, seus produtos e serviços. São Paulo: Futura, 2001.

TAVARES, Fred. Discurso publicitário e consumo: uma análise crítica. Rio de Janeiro: E papers Serviços Editoriais Ltda, 2005. 
From convincing to interacting: some thoughts about contexts and courses of Brazilian advertising

\section{Del convencer a interactuar: algunas reflexiones sobre los contextos y vías de la publicidad brasileña}

\section{Abstract}

From the observation of the transformation proccess of brazilian advertising narrative throughout its history, this article aims at analyzing prevailing trends in advertising at different times. It is show three periods with different ways of approach. Emphasizing contemporary practices, its observes that youth and tecnologies are relevants elements in this scenario.

\section{Keywords}

Advertising. Trends. Argument. Seduction. Interactivity.

\section{Resumen}

A partir de la observación de los procesos de transformación de la narrativa publicitária brasileña a lo largo de su história, este artículo busca analizar tendencias predominantes en la publicidad de diferentes épocas. Se señalan tres periodos con diferentes formas de abordaje. Con énfasis en las prácticas contemporáneas, se observa que la juventud y lãs tecnologias son elementos clave en este escenario.

\section{Palabras-Clave}

Publicidad. Juventud. Tecnologias. Interatividade. 


\section{Expediente}

A revista E-Compós é a publicação científica em formato eletrônico da Associação Nacional dos Programas de Pós-Graduação em Comunicação (Compós). Lançada em 2004, tem como principal finalidade difundir a produção acadêmica de pesquisadores da área de Comunicação, inseridos em instituições do Brasil e do exterior.

\section{E-COMPÓS I www.e-compos.org.br I E-ISSN 1808-2599}

Revista da Associação Nacional dos Programas

de Pós-Graduação em Comunicacão.

Brasília, v.17, n.3, set./dez. 2014

A identificação das edições, a partir de 2008

passa a ser volume anual com três números.

\section{CONSELHO EDITORIAL}

Afonso Albuquerque, Universidade Federal Fluminense, Brasil Alberto Carlos Augusto Klein, Universidade Estadual de Londrina, Brasil Alex Fernando Teixeira Primo, Universidade Federal do Rio Grande do Sul, Brasil Ana Carolina Damboriarena Escosteguy, Pontifícia Universidade Católica do Rio Grande do Sul, Brasi

Ana Gruszynski, Universidade Federal do Rio Grande do Sul, Brasil Ana Silvia Lopes Davi Médola, Universidade Estadual Paulista, Brasil André Luiz Martins Lemos, Universidade Federal da Bahia, Brasi Ângela Freire Prysthon, Universidade Federal de Pernambuco, Brasil Antônio Fausto Neto, Universidade do Vale do Rio dos Sinos, Brasil Antonio Carlos Hohlfeldt, Pontifícia Universidade Católica do Rio Grande do Sul, Brasil Antonio Roberto Chiachiri Filho, Faculdade Cásper Líbero, Brasi Arlindo Ribeiro Machado, Universidade de São Paulo, Brasil Arthur Autran Franco de Sá Neto, Universidade Federal de São Carlos, Brasil Benjamim Picado, Universidade Federal Fluminense, Brasil César Geraldo Guimarães, Universidade Federal de Minas Gerais, Brasil Cristiane Freitas Gutfreind, Pontifícia Universidade Católica do Rio Grande do Sul, Brasil Denilson Lopes, Universidade Federal do Rio de Janeiro, Brasil Denize Correa Araujo, Universidade Tuiuti do Paraná, Brasil Edilson Cazeloto, Universidade Paulista, Brasil

Eduardo Vicente, Universidade de São Paulo, Brasil

Eneus Trindade, Universidade de São Paulo, Brasil

Erick Felinto de Oliveira, Universidade do Estado do Rio de Janeiro, Brasil Florence Dravet, Universidade Católica de Brasilia, Brasil

Gelson Santana, Universidade Anhembi/Morumbi, Brasi Gilson Vieira Monteiro, Universidade Federal do Amazonas, Brasil Gislene da Silva, Universidade Federal de Santa Catarina, Brasil Guillermo Orozco Gómez, Universidad de Guadalajara, México Gustavo Daudt Fischer, Universidade do Vale do Rio dos Sinos, Brasil Hector Ospina, Universidad de Manizales, Colômbia Herom Vargas, Universidade Municipal de São Caetano do Sul, Brasil leda Tucherman, Universidade Federal do Rio de Janeiro, Brasil Inês Vitorino, Universidade Federal do Ceará, Brasil Janice Caiafa, Universidade Federal do Rio de Janeiro, Brasil Jay David Bolter, Georgia Institute of Technology, Estados Unidos Jeder Silveira Janotti Junior, Universidade Federal de Pernambuco, Brasi João Freire Filho, Universidade Federal do Rio de Janeiro, Brasil John DH Downing, University of Texas at Austin, Estados Unidos
José Afonso da Silva Junior, Universidade Federal de Pernambuco, Brasil José Carlos Rodrigues, Pontifícia Universidade Católica do Rio de Janeiro, Brasil José Luiz Aidar Prado, Pontifícia Universidade Católica de São Paulo, Brasil José Luiz Warren Jardim Gomes Braga, Universidade do Vale do Rio dos Sinos, Brasil Juremir Machado da Silva, Pontifícia Universidade Católica do Rio Grande do Sul, Brasil Laan Mendes Barros, Universidade Metodista de São Paulo, Brasi Lance Strate, Fordham University, USA, Estados Unidos Lorraine Leu, University of Bristol, Grã-Bretanha Lucia Leão, Pontifícia Universidade Católica de São Paulo, Brasil Luciana Panke, Universidade Federal do Paraná, Brasil Luiz Claudio Martino, Universidade de Brasília, Brasil Malena Segura Contrera, Universidade Paulista, Brasil Márcio de Vasconcellos Serelle, Pontifícia Universidade Católica de Minas Gerais, Brasil Maria Aparecida Baccega, Universidade de São Paulo e Escola Superior de Propaganda e Marketing, Brasi Maria das Graças Pinto Coelho, Universidade Federal do Rio Grande do Norte, Brasil Maria Immacolata Vassallo de Lopes, Universidade de São Paulo, Brasil Maria Luiza Martins de Mendonça, Universidade Federal de Goiás, Brasil Mauro de Souza Ventura, Universidade Estadual Paulista, Brasil Mauro Pereira Porto, Tulane University, Estados Unidos Nilda Aparecida Jacks, Universidade Federal do Rio Grande do Sul, Brasil Paulo Roberto Gibaldi Vaz, Universidade Federal do Rio de Janeiro, Brasil Potiguara Mendes Silveira Jr, Universidade Federal de Juiz de Fora, Brasil Renato Cordeiro Gomes, Pontifícia Universidade Católica do Rio de Janeiro, Brasil Robert K Logan, University of Toronto, Canadá

Ronaldo George Helal, Universidade do Estado do Rio de Janeiro, Brasil Rosana de Lima Soares, Universidade de São Paulo, Brasi Rose Melo Rocha, Escola Superior de Propaganda e Marketing, Brasil Rossana Reguillo, Instituto de Estudos Superiores do Ocidente, México Rousiley Celi Moreira Maia, Universidade Federal de Minas Gerais, Brasi Sebastião Carlos de Morais Squirra, Universidade Metodista de São Paulo, Brasil Sebastião Guilherme Albano da Costa, Universidade Federal do Rio Grande do Norte, Brasil

Simone Maria Andrade Pereira de Sá, Universidade Federal Fluminense, Brasi Suzete Venturelli, Universidade de Brasília, Brasil

Tiago Quiroga Fausto Neto, Universidade de Brasília, Brasil

Valerio Fuenzalida Fernández, Puc-Chile, Chile

Veneza Mayora Ronsini, Universidade Federal de Santa Maria, Brasi Vera Regina Veiga França, Universidade Federal de Minas Gerais, Brasil

\section{COMISSÃO EDITORIAL}

Cristiane Freitas Gutfreind I Pontifícia Universidade Católica do Rio Grande do Sul, Brasil Irene Machado I Universidade de São Paulo, Brasil

Jorge Cardoso Filho I Universidade Federal do Recôncavo da Bahia, Brasil Universidade Federal da Bahia, Brasil

CONSULTORES AD HOC

Adriana Amaral, Universidade do Vale do Rio dos Sinos, Brasil

Alexandre Rocha da Silva, Universidade Federal do Rio Grande do Sul, Brasi

Arthur Ituassu, Pontifícia Universidade Católica do Rio de Janeiro, Brasil

Bruno Souza Leal, Universidade Federal de Minas Gerais, Brasil

Elizabeth Bastos Duarte, Universidade Federal de Santa Maria, Brasil

Francisco Paulo Jamil Marques, Universidade Federal do Ceará, Brasi

Maurício Lissovsky, Universidade Federal do Rio de Janeiro, Brasil

Suzana Kilpp, Universidade do Vale do Rio dos Sinos, Brasil

Vander Casaqui, Escola Superior de Propaganda e Marketing, Brasi

EDIÇ̃̃O DE TEXTO E RESUMOS I Press Revisão

SECRETÁRIA EXECUTIVA I Helena Stigger

EDITORAÇÃo ELETRÔNICA I Roka Estúdio
COMPÓS I www.compos.org.br

Associação Nacional dos Programas de Pós-Graduação em Comunicação

Presidente

Eduardo Morettin

Universidade de São Paulo, Brasil

eduardomorettin@usp.br

Vice-presidente

Inês Vitorino

Universidade Federal do Ceará, Brasil

ines@ufc.br

Secretária-Geral

Gislene da Silva

Universidade Federal de Santa Catarina, Brasil

gislenedasilva@gmail.com 